\title{
BADANIA NAD EDUKACJĄ POZAFORMALNĄ DOROSLYCH W RFN, ZE SZCZEGÓLNYM UWZGLĘDNIENIEM ANALIZY PROGRAMÓW INSTYTUCJI EDUKACJI DOROSEYCH
}

\begin{abstract}
Słowa kluczowe: badania nad edukacją, edukacja dorosłych, edukacja pozaformalna, instytucje edukacji dorosłych, analiza programów.

Streszczenie: Artykuł przedstawia kierunki badań nad obszarem edukacji pozaformalnej dorosłych prowadzonych w Republice Federalnej Niemiec. Jej popularność jako obszaru badawczego nie maleje od lat 70. ubiegłego wieku mimo wyraźnego wzrostu zainteresowania badaczy fenomenem uczenia się poza instytucjami, w środowiskach ludzkiego życia i pracy. W obszarze niemieckich badań nad pozaformalną edukacją dorosłych można wyróżnić kilka odrębnych nurtów: badania nad procesami nauczania-uczenia się w instytucjach, nad kursami, badania nad funkcjonowaniem instytucji i organizacji, nad profesją edukatora dorosłych i programami oraz badania nad adresatami, uczestnikami i grupami docelowymi ofert edukacyjnych. Autorka artykułu skupia uwagę przede wszystkim na badaniach nad programami instytucji edukacyjnych, ponieważ ten obszar badań nie zajmuje w polskiej edukacji dorosłych ważnego miejsca.
\end{abstract}

\section{Pedagogiczne kontestacje instytucji edukacyjnych}

Edukacja pozaformalna tworzy tradycyjną przestrzeń procesów nauczania - uczenia się dorosłych. Jest lub może być edukacją towarzyszącą człowiekowi przez całe życie, bo przecież ofertę adresuje do wszystkich populacji wiekowych. W przypadku ludzi dorosłych, którzy zakończyli naukę $\mathrm{w}$ formalnym systemie edukacji, udział w kursach, szkoleniach czy krótkich formach upowszechniania wiedzy, jak choćby wykładach czy pogadankach, stanowi częstokroć jedyną okazję do spotkania z profesjonalistami dysponującymi know-how w danej dziedzinie. Tymczasem edukacja formalna i pozaformalna popadły w Polsce w niełaskę. Elżbieta Sarnowska-Temeriusz (2006, s. 14) wyraża pogląd, iż: „Problem istoty i celów edukacji zepchnięto w cień, przesłaniając go prawem człowieka do siedzenia w ławce szkolnej tak długo, jak zechce, albo jak długo da się go w niej utrzymać. Zinstytucjonalizowana edukacja stała się w dużej mierze wypełniaczem czasu, a nie trudną z natury rzeczy drogą własnego rozwoju". Lech Witkowski (2009, 
s. 106) zauważa, że kursy, szkolenia i inne formy kształcenia instytucjonalnego wyposażają „,w sprawność banalnego nawyku schematycznych, bezrefleksyjnych działań (...) Wyobraźmy sobie szkolenia i kursy przysposobienia, po których ludzie wychodzą bardziej wrażliwymi i etycznie dojrzałymi, i filozoficznie oczytanymi, jednym słowem bardziej ludzcy”. O „niewydolności instytucji oświatowych, ich nieadekwatności strukturalnej do zmian kontekstu społecznego i stanu świadomości podmiotów publicznych" pisze Zbigniew Kwieciński (2000, s. 8). Pedagog wskazuje również na „opóźnienie edukacji wobec zmian”: „Wszystkie struktury: organiczne, regulacyjne, sterujące i innowacyjne są dysfunkcjonalne i spóźnione wobec potrzeb i oczekiwań oraz wobec wymagań współczesnej i nowoczesnej nauki o edukacji. Są prawdopodobnie zaporą zmiany społecznej. Dostrzeżenie tego przez reformatorów systemu politycznego może uruchomić działania zmieniające i odwracające ten stan rzeczy w kierunku zaangażowania oświaty we własną transformację oraz w rozwojowe zmiany w sferze publicznej" (Kwieciński, 2011, s. 211). Zresztą krytyka instytucjonalnych form kształcenia odbija się głośnym echem także poza naszymi granicami. Zasadniczo instytucjom zarzuca się skostniałe struktury, nieadekwatność ofert do potrzeb uczących się osób, wyobcowanie z realiów ludzkiego życia i opór przeciwko nowym ideom i koncepcjom, które raz po raz artykułuje polityka oświatowa. $Z$ drugiej strony pojawiają się argumenty za instytucjonalnymi formami kształcenia. Ich orędownicy wskazują na szereg niezastąpionych funkcji instytucji oświatowych: zapewniają systematyczną i wysokojakościową edukację, wychodzą naprzeciw zainteresowaniom i potrzebom edukacyjnym mieszkańców miast i wsi, wnoszą poza tym cenny wkład w ciągły rozwój wiedzy i koncepcji pedagogicznych (Nuissl, 2010, s. 339).

\section{Pozaformalna edukacja dorosłych jako obszar badań empirycznych w Niemczech}

Przegląd współczesnych niemieckich opracowań naukowych przekonuje o tym, że andragodzy poświęcają wiele uwagi aspektom instytucjonalnym edukacji dorosłych, programom pedagogicznym, strukturze uczestników edukacji (badania nad uczestnikami i adresatami ofert), profesjonalizacji kadry pedagogicznej oraz kwestiom współpracy różnorodnych oferentów z otoczeniem społecznym lub, coraz częściej, relacjom pomiędzy wiedzą i umiejętnościami zdobywanymi w kontekstach instytucjonalnych a kompetencjami rozwijanymi w ludzkich światach życia i pracy. Birte Egloff i Jochen Kade (2004, s. 138) reasumują: „W badaniach nad edukacją dorosłych i edukacją ustawiczną można wyróżnić obszar badań nad nauczaniem, uczeniem się i kursami, badania nad instytucjami i organizacjami, nad profesją i programami oraz badania nad adresatami, uczestnikami i grupami docelowymi". Poniżej zostaną naszkicowane, w dużym skrócie, obszary badań nad infrastrukturą instytucji i organizacji edukacji dorosłych, nad uczestnictwem osób dorosłych w ofertach edukacji dorosłych oraz profesjonalizacją kadry pracującej $\mathrm{z}$ osobami dorosłymi. 
Badania nad infrastrukturą instytucji i organizacji edukacji dorosłych stanowią tradycyjny obszar refleksji andragogicznej. „Rozwój uczenia się i edukacji dorosłych jest nie do pomyślenia bez procesów instytucjonalizacji i organizacji” - konstatują Karin Dollhausen i Josef Schrader (2015, s. 175), podkreślając, że do połowy lat 20. ubiegłego wieku procesy te inicjowane były przez poszczególne ruchy społeczne, instytucje czy organizacje (np. ruch robotniczy, kościoły, przedsiębiorstwa) dążące do realizacji partykularnych celów. Dopiero w drugiej połowie XX stulecia pojawiły się pierwsze koncepcje systematycznej organizacji pracy oświatowej z osobami dorosłymi w kontekstach instytucjonalnych, wspartej naukowymi argumentami. Towarzyszył im sprzyjający klimat polityczny, nagłaśniający dyskurs o odpowiedzialności podmiotów publicznych za edukację dorosłego społeczeństwa, tu zwłaszcza o roli samorządów terytorialnych, które - na mocy ustaw krajowych - zobligowano (w różnym stopniu w poszczególnych krajach związkowych) do zapewnienia wszystkim zainteresowanym dorosłym obywatelom dostępu do ofert edukacyjnych. Intencje polityczne zaowocowały m.in. włączeniem uniwersytetów powszechnych (Volkshochschulen) do struktur gminnych, a w następstwie obarczeniem samorządów terytorialnych (np. gmina, powiat) odpowiedzialnością za ich funkcjonowanie. Począwszy od lat 80. XX wieku, wraz z redukcją środków budżetowych na edukację dorosłych, rozwinęły się w nauce nowe dyskursy dotyczące ,edukacji dorosłych jako sektora usług” (Schlutz, 1997) oraz zagadnień związanych z zarządzaniem oświatą w kontekście wymogu zwiększania efektywności usług edukacyjnych w obliczu niższych inwestycji (Tietgens, 1995; Bastian, 2002), w tym także wprowadzania do sektora edukacji dorosłych systemów zarządzania jakością, monitoringu i ewaluacji (Harz, Meisel, 2004; Schöll, 2005). Niemieccy badacze zajmowali w tym dyskursie zróżnicowane stanowiska. Jedni upatrywali zagrożeń w procesach modernizacyjnych, zmierzających do wprowadzenia w systemie edukacji dorosłych reguł znanych i sprawdzonych w sektorze gospodarki (Harney, 2002; za: Dollhausen, Schrader, 2015); inni pokładali w nich nadzieję na rozwój wysokojakościowej oferty edukacyjnej (Ehses, Zech, 1999; za: Dollhausen, Schrader, 2015).

Od lat 90. ubiegłego wieku wyraźnie zaznacza się w niemieckim dyskursie naukowym refleksja na temat konieczności wypracowania solidnych podstaw teoretycznych dla badań nad instytucjami edukacji dorosłych, inspirowana głównie przez teorię systemów Niklasa Luhmanna (2012). Niemniej także w tej kwestii stanowiska badaczy są podzielone (Dollhausen, Schrader, 2015). Podczas gdy jedni optują za przyjęciem perspektywy balansującej między organizacyjno-strukturalnymi, ekonomicznymi i pedagogicznymi aspektami zarządzania edukacją dorosłych (Ehses, Zech, 1999), inni naukowcy akcentują zasadność uwzględnienia w podejściu badawczym ogólnej funkcji edukacji dorosłych, sugerując koncentrację na „wiedzy kontekstualnej” i „świadomości relacyjności” pracowników pedagogicznych instytucji edukacji dorosłych (Schäffter, 2003). Jeszcze inni badacze wypowiadają się za ,,programem pedagogicznym” jako najważniejszym, nadrzędnym medium sterującym instytucją edukacji dorosłych (Kuper, 2004). 
Dollhausen i Schrader (2015) konstatują, iż teoria systemów, choć stale obecna w refleksji naukowej, nie pełni jednak pierwszoplanowej roli w badaniach nad znaczeniem i funkcją organizacji i instytucji w systemie edukacji ustawicznej. Coraz większe grono zwolenników zyskuje natomiast neoinstytucjonalizm ${ }^{1}$ kierujący się zasadą racjonalności. Zdaniem autorów, otwiera on przed badaczami szerokie możliwości zarówno analiz zachowań jednostek w ich bliskim otoczeniu społecznym, w tym w instytucjach wspomagających procesy dostosowania się członków społeczności do wymogów świata zewnętrznego, jak i rozpoznania, na ile rozwój instytucji edukacji dorosłych następuje autonomicznie, w jakim zaś stopniu jest determinowany przez działanie innych instytucji społecznych.

Badania nad uczestnictwem w edukacji dorosłych, czyli studia nad adresatami, uczestnikami i grupami docelowymi edukacji dorosłych ${ }^{2}$ zajmują ważne miejsce w niemieckiej myśli andragogicznej. Dotyczą one człowieka dorosłego, jego zainteresowań, oczekiwań, motywów i barier utrudniających bądź uniemożliwiających uczestnictwo w edukacji. Zresztą pierwsze statystyki dotyczące uczestników ofert edukacji dorosłych pochodzą z końca XIX wieku; w pierwszych dekadach XX wieku - wraz z rozwojem instytucjonalnych form edukacji dorosłych - podjęto nowatorskie próby opisu uczestników ofert w oparciu o ich cechy demograficzne oraz szerszy ,profil społeczny” (Rademacher, 1932; za: v. Hippel, Tippelt, Gebrande, 2018). W perspektywie instytucjonalnej badania nad uczestnikami ofert edukacyjnych generują wiedzę pozwalającą na rozpoznanie zapotrzebowania na edukację w regionach i przygotowanie ofert edukacyjnych adekwatnych do oczekiwań społecznych; dostarczają ponadto organizatorom edukacji dorosłych informacji niezbędnych do prowadzenia marketingu, perspektywicznego planowania oferty i konstruowania programów edukacyjnych (v. Hippel i in., 2018). Warto odnotować, że na przestrzeni ostatnich dwóch dekad koncepcje badań nad aspektami instytucjonalnymi uległy zróżnicowaniu. Wzrosło przede wszystkim zainteresowanie badaczy grupami docelowymi edukacji dorosłych, którzy przyglądają się im przez pryzmat

1 W odróżnieniu od instytucjonalizmu, neoinstytucjonalizm zakłada, że instytucje są dynamiczne i zmienne. Znajdują się w permanentnym procesie rozwoju, nie powodując spowolnienia tempa zmian; są zatem w swoim działaniu racjonalne.

2 Adresatami ofert są osoby, o które winna zabiegać edukacja dorosłych. Jeśli charakteryzują się wspólnymi cechami społeczno-strukturalnymi, mowa jest o grupie docelowej; uczestnicy to osoby, które biorą udział w kursie (Faulstich, Zeuner, 1999). Pojęcie „grupy docelowe” budzi w nauce kontrowersje, ponieważ trudno jest uchwycić, ,w jaki sposób konglomeraty osób konstytuują się jako grupa" (Faulstich, Zeuner, 1999, s. 108). Grupy docelowe nie są w aktualnej debacie o edukacji dorosłych postrzegane jako zbiorowości osób dotkniętych określonym deficytem lub znajdujące się w specyficznej sytuacji życiowej, jak miało to miejsce w ubiegłych dziesięcioleciach (np. osoby o niskich kwalifikacjach zawodowych, osoby bezrobotne, młodzież z rodzin patologicznych, matki samotnie wychowujące dziecko/dzieci itd.). Są to dziś stosunkowo homogeniczne grupy osób mających wspólne zainteresowania: np. chcą nauczyć się technik rysunkowych lub opanować język obcy. 
czynników socjodemograficznych (Huntemann, Reichert, 2017), biografii (badania biograficzne) (Nittel, Marotzki, 1997; Seitter, 1999; Herzberg, 2004), specyfiki środowiskowej (światy życia) (Vester, Oertzen, Geiling, Hermann, Müller, 1993; Barz, Tippelt, 2004) lub - coraz częściej też - pod kątem poziomu posiadanych kompetencji w różnych obszarach społecznego funkcjonowania (Schmidt-Hertha, Gebrande, 2018).

Kolejny obszar badań edukacyjnych nad pozaformalną edukacją dorosłych skupia się wokół problematyki profesji edukatora dorosłych i dróg jego profesjonalizacji. Międzynarodowe badania porównawcze pokazują, że zagadnienia te są szczególnie intensywnie omawiane zwłaszcza w tych krajach, w których po pierwsze funkcjonuje sprawna, szeroko rozbudowana infrastruktura edukacji dorosłych, po drugie edukacja dorosłych jako dyscyplina naukowa cieszy się znacznym prestiżem w środowiskach akademickich i jest powszechnie uznanym kierunkiem studiów wyższych (Seitter, 2015). Należy podkreślić, że problematyka profesjonalizacji w edukacji dorosłych rzadko traktowana jest przez niemieckich badaczy w sposób kompleksowy, choć systematycznie pojawiają się próby całościowego ujęcia profilu zawodowego edukatora dorosłych w kontekście zmian społecznych (globalizacja, internacjonalizacja, indywidualizacja), politycznych (reformy szkolnictwa wyższego) czy koncepcji oświatowych i pedagogicznych (np. uczenie się przez całe życie, zwrot ku uczeniu się nieformalnemu) (Arnold, Lermen, 2012; Egetenmeyer, Schüßler, 2012). Wśród nurtów badawczych ogniskujących się wokół profesjonalizacji edukatorów dorosłych wyraźnie wyłania się kilka głównych kierunków. Po pierwsze są to studia nad profesją edukatora dorosłych usytuowaną w określonej rzeczywistości społecznej i zawodowej, przedstawiające za pomocą liczb i innych danych (np. regulacje prawne, zakres zadań, formy zatrudnienia, liczba realizowanych godzin, wysokość honorariów) edukację dorosłych jako heterogeniczny obszar aktywności zawodowej (Seitter, 2015; Kraft, 2007, 2018). Po drugie uwagę badaczy przyciąga sytuacja akademickiej edukacji dorosłych, zwłaszcza programy kształcenia przyszłych edukatorów dorosłych na różnych (nie tylko pedagogicznych) kierunkach studiów oraz oferty kierowane do praktyków edukacji dorosłych w ramach studiów podyplomowych lub innych form kształcenia i doskonalenia zawodowego (Witt, Müller, 2012). Kolejny nurt badawczy obejmuje studia nad poszczególnymi aspektami działalności zawodowej specjalistów edukacji dorosłych, tu zwłaszcza uwarunkowania i proces rozwoju kompetencji w dziedzinie nauczania, doradztwa, ewaluacji, zarządzania edukacją dorosłych i współpracy z szeroko rozumianym środowiskiem społecznym (Dinkelaker, v. Hippel, 2015). Do tych tradycyjnych obszarów badań empirycznych nad profesją i profesjonalizmem edukatora dorosłych dołącza obecnie problematyka uznawalności i certyfikacji kompetencji osób zatrudnionych w instytucjach edukacji dorosłych, nieposiadających udokumentowanych kwalifikacji do pracy z „dorosłym uczniem” (Gnahs, 2010; Gruber, 2018). 


\section{Studia nad programami instytucji edukacji dorosłych}

Programy upubliczniane przez instytucje edukacji dorosłych stanowią, obok badań nad ogólnymi prawidłowościami funkcjonowania tych placówek, tradycyjny przedmiot zainteresowania badaczy. Program, słowo pochodzące z języka greckiego prógramma, ma szeroki zakres semantyczny; może oznaczać: „,plan zamierzonych czynności, przedsięwzięć”, ,założenia, postulaty i cele jakiejś działalności”, „repertuar teatru, opery itp., „opis tego repertuaru wydrukowany w formie broszury, ulotki lub w gazecie”, „broszurę zawierającą informacje o danym przedstawieniu, koncercie itp.” czy „zakres wiedzy objętej nauczaniem szkolnym lub akademickim, też: wykaz przedmiotów objętych takim nauczaniem" (Bańko, 2005, s. 1022). Analizy programów dokonywane przez badaczy instytucji edukacji dorosłych dotyczą opublikowanych zapowiedzi oferty edukacyjnej i innych usług świadczonych przez instytucje edukacji dorosłych (np. oferta kursów doskonalenia zawodowego dla pracowników). Pełnią one w pierwszym rzędzie funkcję informacyjną odnośnie do aktualnej oferty kursowej bądź marketingową (pozyskanie uczestników); w dalszej kolejności promują organizatora ofert i legitymują działalność instytucji (Nolda, 2018, s. 433). „Program jest zwierciadłem organizacji lub instytucji edukacyjnej. Daje wgląd w przemiany i/lub ciągłość, które na drodze badań można ustalić i zrozumieć. Historię programów edukacyjnych w danym społeczeństwie można opisać i oparłszy ją na empirii, wykorzystać do wyjaśnienia rozwoju krajobrazu edukacyjnego" (Gieseke, 2015, s. 170).

Badania nad programami instytucji edukacji dorosłych polegają na analizach tekstów, dokumentów, informacji programowych poszczególnych instytucji. Są $\mathrm{z}$ reguły prowadzone w odniesieniu do konkretnych dziedzin edukacji (np. edukacja kulturalna, edukacja obywatelska, edukacja językowa) lub wybranych grup adresatów, celów czy założeń dydaktycznych. Przykładowo programy uniwersytetów powszechnych, publikowane od najwcześniejszych lat ich działalności, stanowią istotny zbiór dokumentów historycznych wykorzystywanych współcześnie w debatach politycznych, procesach planowania aktualnej i przyszłej oferty oraz jako ważne źródło inspiracji do przemyśleń dydaktycznych (Tietgens, 1998). Zresztą badania nad programami instytucji edukacyjnych zawdzięczają swój rozkwit właśnie uniwersytetom powszechnym, które - jako organizatorzy ofert edukacyjnych zajmujący szczególnie stabilną pozycję na rynku oświatowym, realizujący obszerną ofertę edukacyjną w różnych dziedzinach wiedzy i otwarci na różne grupy społeczne (są instytucjami publicznymi, finansowanymi w dużej mierze ze środków budżetowych) - przywiązywały istotne znaczenie do komunikowania się z otoczeniem społecznym za pomocą drukowanych programów. Aktualnie badacze borykają się z problemem natury raczej technicznej, jakim jest ewidencja i analiza systematycznie uaktualnianych ofert programowych upublicznianych na stronach internetowych dziesiątek tysięcy organizatorów edukacji dorosłych (Nolda, 2018). 
W obrębie prowadzonych na przestrzeni ostatnich lat studiów empirycznych nad programami instytucji edukacji dorosłych rozróżnia się: badania pełnej próby, stanowiące raczej rzadkość, badania oparte na próbie reprezentatywnej, studia przypadków oraz badania poprzeczne i podłużne (Nolda, 2017). W pierwszym rzędzie badacze programów skupiają uwagę na fluktuacji ofert; analiza programów pozwala odpowiedzieć na pytanie, w jakich latach określone treści i przedmioty były kierowane do adresatów, kiedy zaś - prawdopodobnie w wyniku badań rynku prowadzonych przez instytucje edukacyjne - znikały z ich oferty. Jakościowe analizy programów dotyczą przede wszystkim pojedynczych tekstów zapowiadających określone kursy poświęcone konkretnym tematom. Im bardziej szczegółowa jest informacja zawarta w programach, tym więcej wiedzy dostarcza badaczom na temat instytucji i warunków ramowych jej działania (np. polityka oświatowa, źródła finansowania), grupy adresatów (ich zapotrzebowanie i oczekiwania, status społeczny, wykształcenie), treści procesów nauczania-uczenia się (wiedza teoretyczna lub praktyczna). Często stosowaną metodę w badaniach jakościowych nad programami, służącą zwłaszcza opracowywaniu danych empirycznych, stanowi obiektywna hermeneutyka zaproponowana przez niemieckiego socjologa Ulricha Oevermanna (por. Urbaniak-Zając, 2010). Równie dużą popularność zyskała krytyczna analiza dyskursu rozpatrująca jego językoznawcze elementy, np. konotacje kluczowych zwrotów, ich podteksty, pragmatyczne intencje nadawcy czy relacje pomiędzy językiem a ludzkim myśleniem i kulturą.

Wiltrud Gieseke (2015) prezentuje niektóre z wyników analiz programowych przeprowadzonych w ramach studiów nad programami pedagogicznymi instytucji edukacji dorosłych:

- Świadczą one o daleko idącej autonomii koncepcji edukacji poszczególnych instytucji mimo ich elastyczności i zdolności adaptacji do zmian prowokowanych „duchem czasów” i przeobrażeniami politycznymi;

- Pokazują wysoką zdolność adaptacyjną instytucji i edukatorów dorosłych do aktualnych wymogów oraz zależność programów od profesjonalnych kompetencji pracowników i współpracowników instytucji, którzy - działając w jednakowych lub porównywalnych społecznych warunkach strukturalnych, osiągają silnie zróżnicowane efekty;

- Wskazują na rosnącą rolę określonych problemów i kompetencji w poszczególnych programach pedagogicznych i malejące znaczenie struktury przedmiotów (podział na przedmioty);

- Odzwierciedlają zmiany w koncepcjach pracy oświatowej zachodzące pod wpływem nowych badań naukowych i interpretacji ich wyników;

- Potwierdzają efekty osiągane dzięki realizacji określonych programów politycznych;

- Dają wgląd w specyficzne podejścia do wiedzy w ramach danego przedmiotu i danej instytucji, umożliwiając jednocześnie porównanie z innymi instytucjami. 
Przykładowo, programy edukacji kulturalnej w uniwersytetach powszechnych, jak stwierdza K. Groote (2012), świadczą o tym, że oferta tych instytucji rozwija się „między ciągłością a innowacją”. W latach 70 . XX wieku dominowały w ofercie kursy o charakterze receptywnym (z zakresu historii sztuki, muzyki, odwiedziny w teatrach i operach), podczas gdy współcześnie trzon programu tworzą „kursy kreatywne”, stanowiące odpowiedź na zapotrzebowanie uczestników, którym nie tyle chodzi o zdobywanie wiedzy, ile rozwój umiejętności oraz możliwość ekspresji i przeżywania procesu własnej twórczości. Programy uniwersytetów powszechnych świadczą ponadto o ciągłości oferty; pokazują, że kursy cieszące się popularnością wśród słuchaczy znajdują kontynuację; ich forma ulega zróżnicowaniu uwzględniającemu umiejętności uczestników (kursy dla początkujących i zaawansowanych) oraz ich specyficzne oczekiwania. Uwidoczniają również pewne trendy, które w konkretnych latach szczególnie silnie zdominowały ofertę edukacyjną (np. zainteresowanie tańcem). Jedne z nich szybko straciły swoją atrakcyjność; inne w gruntowny sposób przekształciły dział „,edukacji kulturalnej” (np. zmiany w obszarze fotografii wraz z przejściem z fotografii analogicznej do cyfrowej). Na kształt oraz jakość programów edukacji kulturalnej - podkreśla K. Groote (2012), obok zainteresowań adresatów ofert, znaczący wpływ wywierają osoby prowadzące kursy, z reguły specjaliści w danej dziedzinie współpracujący $\mathrm{z}$ uniwersytetem powszechnym na podstawie umowy-zlecenia. Działając na co dzień w galeriach sztuki czy centrach kultury, dostarczają cennych impulsów do modyfikowania oferty uniwersytetów powszechnych i tworzą pomosty łączące instytucję edukacyjną ze środowiskami twórców sztuki i jej odbiorcami. Badacze akcentują, że niemałym osiągnięciem uniwersytetów powszechnych jest zmiana ich wizerunku, która nastąpiła na przestrzeni kilku ostatnich dziesięcioleci. $\mathrm{Z}$ instytucji utożsamianych $\mathrm{z}$ amatorstwem $\mathrm{w}$ dziedzinie kultury i sztuki zdołały włączyć ten obszar edukacji w nurt nowoczesnej edukacji estetycznej (Schlutz, 2018). Trendem od lat dominującym pozostają ,malowanie - rysowanie - techniki druku"; na znaczeniu zyskują jednak cielesność i rytmika (co uwidacznia również rosnąca popularność kursów edukacji zdrowotnej) (Schlutz, 2018).

Jako kolejny przykład badań nad programami może posłużyć edukacja w dziedzinie języków obcych. W jej przypadku zapowiedzi kursów językowych stanowią przeważnie przedmiot badań statystycznych (Nolda, 2017), które udzielają odpowiedzi na pytanie, jakie języki, ile kursów, dla jakich grup docelowych i na jakich poziomach nauczania znalazło się w ofercie badanej instytucji czy, syntetycznie, w danym regionie, na przestrzeni określonego czasu. Szczegółowe analizy danych dostarczają wiedzy zarówno na temat profilu oferentów kursów językowych (np. czy kurs realizowany jest przez „szkołę” języków obcych czy instytucję o bogatszym niż językowy profilu działania), jak i szerszych, kulturowych czy politycznych uwarunkowań procesów nauczania-uczenia się. Egzemplarycznie, badania nad programami uniwersytetu powszechnego w Dreźnie (Gieseke, Opelt, 2003; za: Nolda, 2017) wykazały, że w latach 1990-1997 oferty kursów 
językowych wyraziście odzwierciedlały zmiany dokonujące się po upadku muru berlińskiego i zjednoczeniu obu państw niemieckich. Dominujące w NRD kursy języków państw bloku socjalistycznego zostały niemal całkowicie wyparte przez kursy języków zachodnioeuropejskich.

W kontekście studiów nad programami kursów językowych dla dorosłych warto jednak zaznaczyć, że zasadniczo badania nad edukacją w dziedzinie języków obcych koncentrują się w Niemczech na populacji dzieci i młodzieży, mając na celu przede wszystkim optymalizację edukacji szkolnej, podczas gdy procesy nauczania-uczenia się osób dorosłych traktowane są w dalszym ciągu raczej marginalnie (Nolda, 2017). Analizom programów podejmowanych przez andragogów przyświeca odpowiednio w większym stopniu dążenie do rozpoznania sektora edukacji dorosłych i instytucji aktywnych w obszarze nauczania języków obcych niż specyfiki procesów rozwoju kompetencji językowych dorosłego społeczeństwa. W literaturze przedmiotu pojawiają się postulaty intensyfikacji badań jakościowych nad programami kursów języków obcych, także badań nad kursami (ich przebiegiem, dydaktyką, rolą nauczyciela, interakcjami pomiędzy uczestnikami etc.) oraz badań nad biograficznymi uwarunkowaniami rozwoju kompetencji w dziedzinie komunikowania się w językach obcych.

\section{Podsumowanie: badania nad instytucjami - perspektywa międzynarodowa}

Środowisko niemieckich andragogów wyraża przekonanie o konieczności rozszerzenia i natężenia eksploracji procesów i zjawisk zachodzących w sektorze edukacji pozaformalnej, której fundamentem są instytucje i organizacje działające na pluralistycznym rynku oświatowym. Wymóg ten jest konsekwencją m.in. rosnącego znaczenia ponadnarodowych struktur zarządzania i zwiększającej się liczby zagranicznych lub międzynarodowych podmiotów oferujących usługi edukacyjne na krajowym rynku. Dollhausen i Schrader (2015) wskazują na kilka palących wyzwań wynikających z postępującej internacjonalizacji europejskich sektorów edukacji dorosłych: Po pierwsze oferenci pozaformalnej edukacji dorosłych winni uwzględnić w swoich strategiach rozwoju zarówno przeobrażenia zachodzące w obszarze struktur zarządzania, jak i obecność na krajowych rynkach nowych, zagranicznych organizatorów oferty edukacyjnej. Po drugie badacze sektora pozaformalnej edukacji dorosłych, zwłaszcza jej aspektów instytucjonalnych, są konfrontowani z wymogiem otwarcia się na dyskursy prowadzone na płaszczyźnie europejskiej i włączenia się - choćby poprzez prezentację wyników badań empirycznych na łamach renomowanych czasopism - do międzynarodowego nurtu eksploracji procesów zachodzących w obszarze instytucjonalnym. Przykładowo odpowiedzi wymaga pytanie o korelacje (np. znaczenie strukturotwórcze) pomiędzy krajowymi politykami w dziedzinie kształcenia ustawicznego, politykami społecznymi, politykami i strategiami rynku pracy a rozwojem sektora edukacji pozaformalnej. Popularny zwłaszcza w krajach anglosaskich nurt badań nad „educational leadership and managament" (Briggs, Colleman, 2007; za: Dollhausen, 
Schrader, 2015, s. 180-181) wyłania bogatą paletę problemów wymagających empirycznych eksploracji: Jaki jest wkład instytucji edukacji dorosłych w proces tworzenia, zapewniania i rozwoju możliwości edukacyjnych dla społeczeństwa? W jaki sposób struktura instytucji, organizacja pracy, strategiczne decyzje w sferze zarządzania oraz kompetencje kadry zarządzającej, administracyjnej i pedagogicznej przekładają się na jakość pracy i osiągane przez instytucję edukacyjną efekty? Jaka zachodzi korelacja pomiędzy sektorem pozaformalnej edukacji dorosłych a realizacją postulatów zawartych w koncepcji uczenia się przez całe życie? Zbyt luźne i powierzchowne pozostaje dotychczas sprzężenie między badaniami nad organizacjami a centralnymi pytaniami nauk pedagogicznych, istotnymi w kontekście rozwoju jakości procesów nauczania-uczenia się i tworzenia adekwatnych uwarunkowań sprzyjających tym procesom - konstatują Dollhausen i Schrader (2015). Tymczasem pogłębione badania w tym obszarze, empirycznie dokumentujące funkcjonowanie mechanizmów kształtowania i sterowania potencjałem instytucjonalnym, mogłyby wesprzeć zarówno praktykę edukacji dorosłych, jak i politykę oświatową, przyczyniając się do podniesienia jakości ofert edukacyjnych i otwarcia się edukacji na szerokie kręgi społeczne.

\section{Bibliografia}

1. Arnold, R., Lermen, M. (2012). Professionalisierungsverhalten und Wissenschaftliche Weiterbildung im Kontext des Lebenslangen Lernens. W: R. Egetenmeyer, I. Schüßler (Hrsg.), Akademische Professionalisierung in der Erwachsenenbildung/Weiterbildung (s. 201-212). Baltmannsweiler: UTB.

2. Barz, H., Tippelt, R. (2004). Weiterbildung und soziale Milieus in Deutschland. Adressaten und Milieuforschung zu Weiterbildungsverhalten und-Interessen. Bielefeld: W. Bertelsmann Verlag.

3. Bańko, M. (red.), (2005). Wielki stownik wyrazów obcych PWN. Warszawa: Wydawnictwo Naukowe PWN.

4. Bastian, H. (2002). Wirtschaftliches Handeln - ein Lernprozess für die Weiterbildung. W: W. Beer, J. Knoll (Hrsg.), Pädagogisch denken - wirtschaftlich handeln (s. 57- 64). Bielefeld: W. Bertelsmann Verlag.

5. Briggs, A., Coleman, M. (Eds.), (2007). Research Methods in Educational Leadership and Management. Los Angeles: Sage Publications Ltd.

6. Dinkelaker, J., v. Hippel, A. (Hrsg.), Erwachsenenbildung in Grundbegriffen. Stuttgart: W. Kohlhammer.

7. Dollhausen, K., Schrader, J. (2015). Weiterbildungsorganisationen. W: J. Dinkelaker, A. v. Hippel (Hrsg.), Erwachsenenbildung in Grundbegriffen (s. 174-182). Stuttgart: W. Kohlhammer.

8. Egetenmeyer, R, Schüßler, I. (2012). Aktuelle Professionalisierungsansätze in der Erwachsenenbildung - bildungspolitische Einordnung und professionalitätsbezogene Systematik. W: I. Sgier, S. Lattke (Hrsg.), Professionalisierungsstrategien der Erwachsenenbildung in Europa. Entwicklungen und Ergebnisse aus Forschungsprojekten (s. 17-34). Bielefeld: W. Bertelsmann Verlag. 
9. Egloff, B., Kade, J. (2004). Erwachsenenbildungsforschung. W: H.-H. Krüger, C. Grunert (Hrsg.), Wörterbuch Erziehungswissenschaft (s. 135-141). Wiesbaden: Verlag für Sozialwissenschaften.

10. Faulstich, P., Zeuner, Ch. (1999). Erwachsenenbildung - eine handlungsorientierte Einführung. Weinheim: Juventa.

11. Gieseke, W. (2015). Programme und Angebote. W: J. Dinkelaker, A. v. Hippel (Hrsg.), Erwachsenenbildung in Grundbegriffen (s. 165-173). Stuttgart: W. Kohlhammer.

12. Gieseke, W., Opelt, K. (2003). Erwachsenenbildung in politischen Umbrüchen. Das Programm der Volkshochschule Dresden 1945-1997. Opladen: Leske + Budrich.

13. Gnahs, D. (2010). Kompetenzen - Erwerb, Erfassung, Instrumente. Bielefeld: W. Bertelsmann Verlag.

14. Groote, K., de (2012). Kulturelle Bildung im Alter. W: H. Bockhorst, V.-I. Reinwand, W. Zacharias (Hrsg.), Handbuch Kulturelle Bildung (s. 822-824). München: kopaed.

15. Gruber, E. (2018). Kompetenzanerkennung und - zertifizierung für in der Erwachsenenbildung/Weiterbildung Tätige. W: R. Tippelt, A. v. Hippel (Hrsg.), Handbuch Erwachsenenbildung/Weiterbildung (t. 2, s. 1088-1108). Wiesbaden: Springer VS.

16. Harney, K. (2002). Weiterbildung aus der Sicht des Bildungsmanagements. Hessische Blätter für Volksbildung, nr 2(52), s. 125-136.

17. Herzberg, H. (2004). Biographie und Lernhabitus. Eine Studie in Rostocker Werftarbeitermilieu. Frankfurt am Main: Campus.

18. Hippel, A. v., Tippelt, R., Gebrande, J. (2018). Adressaten- Teilnehmer- und Zielgruppenforschung in der Erwachsenenbildung. W: R. Tippelt, A. v. Hippel (Hrsg.), Handbuch Erwachsenenbildung/Weiterbildung (t. 2, s. 1131-1147). Wiesbaden: Springer VS.

19. Huntemann, H., Reichert, E. (2017). Volkshochschul-Statistik: 55. Folge, Arbeitsjahr 2016. Bonn: Deutsches Institut für Erwachsenenbildung.

20. Ehses, C., Zech, R. (1999). Professionalität als Qualität in der Erwachsenenbildung. W: R. Zech, C. Ehses (Hrsg.), Organisation und Lernen (s. 13-57). Hannover: Expressum.

21. Kraft, S. (2007). Die Situation der Beschäftigten in der Weiterbildung - ein Blick in die Realität und Perspektiven für die Zukunft. Außerschulische Bildung, $n r$ 2(38), s. $188-195$.

22. Kraft, S. (2018). Berufsfeld Weiterbildung. W: R. Tippelt, A. v. Hippel (Hrsg.), Handbuch Erwachsenenbildung/Weiterbildung (t. 2, s. 1109-1128). Wiesbaden: Springer VS.

23. Hartz, S., Meisel, K. (2004). Qualitätsmanagement. Bielefeld: W. Bertelsmann Verlag.

24. Kuper, H. (2004). Das Thema „Organisation” in den Arbeiten Luhmanns über das Erziehungssystem. W: D. Lenzen (Hrsg,), Irritationen des Erziehungssystems. Pädagogische Resonanzen auf Niklas Luhmann (s. 122-151). Frankfurt am Main: Suhrkamp Taschenbuch.

25. Kwieciński, Z. (2000). Pedagogika i edukacja wobec wyzwania kryzysu i gwałtownej zmiany społecznej. W: Z. Kwieciński (red.), Alternatywy myślenia o/dla edukacji (s. 7-12). Warszawa: IBE.

26. Kwieciński, Z. (2011). Cztery i pół. Preliminaria-Liminaria-Varia. Wrocław: Wydawnictwo Naukowe DSW.

27. Luhmann, N. (2012). Systemy społeczne. Zarys ogólnej teorii. Kraków: Zakład Wydawniczy NOMOS. 
28. Nittel, D., Marotzki, W. (Hrsg.), (1997). Berufslaufbahn und biografische Lernstrategien. Baltmannsweiler: Schneider Verlag Hohengehren.

29. Nolda, S. (2017). Fremdsprachen lernen. Qualitative Zugänge. Bielefeld: W. Bertelsmann Verlag.

30. Nolda, S. (2018). Programmanalyse in der Erwachsenenbildung/Weiterbildung Methoden und Forschungen. W: R. Tippelt, A. v. Hippel (Hrsg.), Handbuch Erwachsenenbildung/Weiterbildung (t. 1, s. 433-449). Wiesbaden: Springer VS.

31. Nuissl, E. (2010). Ordnungsgrundsätze der Erwachsenenbildung in Deutschland. W: R. Tippelt, A. v. Hippel (Hrsg.), Handbuch Erwachsenenbildung/Weiterbildung (s. 329-346). Wiesbaden: VS Verlag für Sozialwissenschaften.

32. Rademacher, L. (1932). Zur Sozialpsychologie des Volkshochschulhörers. Zeitschrift für angewandte Psychologie, $n r$ 43, s. 461-486.

33. Sarnowska-Temeriusz, E. (2006). Wprowadzenie. W: Instytut Badań Literackich PAN (wyd.), Edukacja humanistyczna w nowym stuleciu (s. 13-15). Wrocław: Instytut Badań Literackich PAN, Zakład Narodowy im. Ossolińskich - Wydawnictwo.

34. Schäffter, O. (2003). Erwachsenenpädagogische Organisationstheorie. W: W. Gieseke (Hrsg,), Institutionelle Innensichten der Weiterbildung (s. 59-81). Bielefeld: W. Bertelsmann Verlag.

35. Schlutz, E. (1997). Erwachsenenbildung als Dienstleistung. Grundlagen der Weiterbildung - Praxishilfen, $n r$ 10, s. 1-18.

36. Schlutz, E. (2018). Weiterbildung und Kultur. W: R. Tippelt, A. v. Hippel (Hrsg.), Handbuch Erwachsenenbildung/Weiterbildung (t. 2, s. 895-911). Wiesbaden: Springer VS.

37. Schmidt-Hertha, B., Gebrande, J. (2018). Large Scale Assessments in der Erwachsenenbildung/Weiterbildung. W: R. Tippelt, A. v. Hippel (Hrsg.), Handbuch Erwachsenenbildung/Weiterbildung (t. 1, s. 415-432). Wiesbaden: Springer VS.

38. Schöll, I. (2005). Marketing in der öffentlichen Weiterbildung. Bielefeld: W. Bertelsmann Verlag.

39. Seitter, W. (1999). Riskante Übergänge in die Moderne. Vereinskulturen, Bildungsbiographien, Migranten. Opladen: Leske + Budrich.

40. Seitter, W: (2015). Profession und Professionalität. W: Dinkelaker, J., v. Hippel, A. (Hrsg.), Erwachsenenbildung in Grundbegriffen (s. 87-92). Stuttgart: W. Kohlhammer.

41. Tietgens, H. (1995). Wirtschaftlichkeit und Bildungsverständnis. DIE Zeitschrift für Erwachsenenbildung, $n r$ 2, s. 38.

42. Tietgens, H. (1998). Zur Auswertung von Arbeitsplänen der Volkshochschulen. W: S. Nolda, K. Pehl, H. Tietgens (Hrsg.), Programmanalysen. Programme der Erwachsenenbildung als Forschungsobjekte (s. 61-138). Frankfurt am Main: Deutsches Institut für Erwachsenenbildung.

43. Urbaniak-Zając, D. (2010). O obiektywnej hermeneutyce jako metodzie interpretacji danych empirycznych. Teraźniejszość - Człowiek - Edukacja, nr 1(49), s. 7-18.

44. Vester, M., Oertzen, P., Geiling, H., Hermann, T., Müller, D. (1993). Soziale Milieus im gesellschaftlichen Strukturwandel. Zwischen Integration und Ausgrenzung. Köln: Bund-Verlag.

45. Witkowski, L. (2009). Ku integralności edukacji i humanistyki II. Postulaty, postacie, pojęcia, próby. Odpowiedź na Księgę jubileuszową. Toruń: Wydawnictwo Adam Marszałek. 
46. Witt, S., Müller, A.-L. (2015). Dokumentation der Studienmöglichkeiten der Erwachsenenbildung/Weiterbildung unter Einbezug von berufsbegleitenden und weiterbildenden Studiengängen in Deutschland. Pobrane z: http://www.die-bonn.de/ $\mathrm{id} / 31784$ (26.01.2019).

\section{RESEARCH ON NON-FORMAL ADULT EDUCATION IN THE FEDERAL REPUBLIC OF GERMANY, WITH A SPECIAL REGARD TO ANALYSIS OF PROGRAMS OF ADULT EDUCATION INSTITUTIONS}

Keywords: educational research, adult education, non-formal education, adult education institutions, analysis of programs.

Summary: The article presents the directions of research on the area of non-formal education of adults run in Germany. Its popularity as a research area has not decreased since the 1970s, despite a clear increase in the interest of researchers in the phenomenon of learning outside institutions. In the area of research on non-formal adult education, one can distinguish several separate trends: research on teaching learning processes in institutions, over courses, research on the functioning of institutions and organizations, over professions and programs, and research on addressees, participants and target groups. The author of the article focuses primarily on research on programs of educational institutions, because this area of research does not take up an important place in Polish adult education.

Dane do korespondencji:

Prof. dr hab. Ewa Przybylska

Szkoła Główna Gospodarstwa Wiejskiego w Warszawie

Katedra Edukacji i Kultury

e-mail ewa_przybylska sggw.pl 